\title{
Transition in East Germany: A British View ${ }^{*}$
}

\author{
Vincent Edwards / Peter Lawrence ${ }^{* *}$
}

The article reviews the process whereby two British academics (with prior knowledge and experience of both the FRG and GDR) developed in 1990 a research project to investigate how an East German company made the transition from communism to privatisation. The project soon developed from a longitudinal study of one company to encompass a range of companies differentiated by location, industry, privatisation stage and mode, and owner origins. The analysis of the interview data permitted the identification of patterns and commonalties of the emergence of corporate strategy. The authors portray the main characteristics of different phases of that process and indicate that not every company had progressed through all phases of the process.

Der Artikel beschreibt die Ergebnisse von zwei britischen Wissenschaftlern (mit Vorkenntnissen und Erfahrungen sowohl zur BRD als auch zur DDR) aus einem Projekt, das 1990 begonnen wurde, um den Übergang eines Unternehmens vom Kommunismus zur Privatisierung zu erforschen. Das Projekt wurde bald von einer Längsschnittstudie eines Unternehmens durch Einbeziehung weiterer Firmen verschiedener geographischer Lage, Industriezweige, Privatisierungsstadien und -wege und Herkunft der Eigentümer erweitert. Die Analyse der Interviewdaten erlaubt die Identifizierung von Mustern und Gemeinsamkeiten des Entstehens der Unternehmensstrategie. Die Verfasser beschreiben die Hauptmerkmale der verschiedenen Phasen dieses Prozesses und zeigen auf, daß nicht jede Firma bisher alle Phasen bewältigt hat.

\footnotetext{
Manuscript received: 19.10.95, accepted: 28.11.95

** Vincent Edwards, born 1947, Head of Research at the Business School, Buckinghamshire College of Brunel University, Director of the Centre for Research into East European Business (CREEB), Major areas of research interest: management practice, change and development in central and eastern Europe and Russia.

Peter Lawrence, born 1937, Professor of Comparative Management at Loughborough University Business School, Major areas of research interest: the engineering dimension in the national economy, comparative management and the nature of management work.
} 
Both the authors are British nationals, speak English as a first language, and have full-time jobs in the United Kingdom. Vincent Edwards is Head of Research at the Buckinghamshire College Business School; Peter Lawrence is Professor of International Management at the Loughborough University Business School. Both of us speak German, and Edwards in fact has a modern languages first degree from Cambridge. What is more we both have longstanding German interests and associations. Edwards has spent several periods in both East and West Germany, and his institution, Buckinghamshire College, has a relationship with the Humboldt University going back to the early 1970s. His interest in East German management began as a consequence of this (Edwards 1979). Lawrence has been a visiting professor at the University of Konstanz, and has done extensive field work in West Germany; his first four books were on German topics, including a book offering a general characterisation of management in West Germany (Lawrence 1980).

\section{Getting Started}

Both of us were excited by the events of the 9th November 1989, and followed subsequent developments with great interest. In the summer of 1990, after currency union but before re-unification, we got together to discuss a possible research initiative in East Germany. At that time there was a widespread view in the United Kingdom that the transition in East Germany would be short-lived and only of passing interest and that within a few years East Germany would be fully subsumed in a unified German economy. We held this view to be one of false imputations of transition.

Our original idea was to try to get access to one, decent-sized company in East Germany, and to trace its fortunes from the end of communism up to the time of privatisation.

We thought and hoped that this would enable us to do two related things:

- construct a before and after picture of the company; be able to describe its form and operations in the late communist period, and then confront this with its state in say early 1991.

- 'stay with' the company, visit it repeatedly, and be able to document the progress of its transition from the command economy to the free market economy.

\section{Pharma AG}

Thanks to the good and long-standing relationship between Buckinghamshire College and the Humboldt University we were well-received at the latter institution, helped with background information and general orientation, and given a privileged introduction to an East German pharmaceuticals company. In 
our subsequent book (Edwards / Lawrence 1994) we refer to this company as Pharma VEB until re-unification and then identify it as Pharma AG. In the Spring of 1991 we made our first visit to Pharma, and this company could hardly have been more helpful.

On the first visit we were 'launched' with a magnificent presentation by one of the senior managers on the history, structure and operations of Pharma, together with supporting documentation. We were told we could go back whenever we liked and talk to whoever we liked.

So began a series of visits to Pharma, of which the most recent was in the Summer of 1994 (and by the time the article is published we expect to have returned). On these visits we always talked to our liaison manager and his assistant, but also came to interview many of the functional heads and senior managers as well as representatives of the Works Council.

In this way we became privileged accessories to an exciting story. We learned about Pharma under communism, and heard about the events at the time the GDR collapsed. At the time of our field visit in May 1991 Pharma AG was in a desperate state. It had lost its East European markets in the confusion following the fall of the communist regimes in other states, and especially in the former USSR, and in the wake of the break up of COMECON. Its domestic East German market was invaded by West German competition, and Pharma faced the challenge of achieving good manufacturing practice (GMP) standards.

Yet by our next visit the fortunes of Pharma AG had taken a marked turn for the better. The company was in the early stages of a boom, based on renewed sales to the CIS (former USSR) on the basis of Hermes-Krediten. A massive investment programme followed, with re-organisation, restructuring, and the attainment of GMP status.

To us as intermittent, foreign visitors one of the most spectacular developments in this period was the physical transformation of the plant.

In the course of a few months we witnessed the transition from Schrotthaufen to an attractive, modern factory with all the facilities and amenities that this designation implies.

The company was slow to be privatised, no doubt in part because of its standing and profitability. Finally it was bought by an Italian pharmaceuticals company, this acquisition being fully effective from early 1993. The new owner did successfully integrate Pharma into its overall operations, and the resulting enterprise continues to be profitable. This integration, however, did involve a marked break with Pharma tradition and a far-reaching change of role which was not to everyone's liking. So by the time we started to write our book we had traced the fortunes of Pharma up to and into privatisation, and could confirm that this had been a commercial success even if there were human costs. 


\section{Widening the Scope of the Study}

Our easy and fortunate access to Pharma encouraged us to try to enlarge the scope of the study. This may not seem much of a challenge to people on the inside, but if you are a foreigner with a full-time job in another country, what one has to do to get access to hard-pressed East German companies awaiting privatisation, is not immediately obvious. But again, it turned out to be easier than it looked. The son of one of our Humboldt contacts founded his own company: we were introduced and visited it regularly.

Another of our Humboldt contacts had become a member of the Aufsichtsrat on a VEB that had been the subject of a management buy out.

We were given access to this firm. Another of our contacts had become a member of the Land Government of one of the new federal states, and this led both to ministerial introductions and to some new companies in this Land. Then another contact, a West German professor, had a doctoral student who had surveyed some companies in the former GDR, and we made contact with all of these.

The resulting sample was not enormous, it was scarcely into double figures, but it gave us a lot of variety in the sense of:

- companies in four out of the five new federal states

- a good spread of industries, including some boom ones (construction) and some in severely threatened sectors (mechanical engineering).

- the sample included two management buy-outs and one new company

- we had a sample that included companies variously bought by (West) Germans, Dutch and Italians as well as some still (1994) awaiting privatisation.

But most important of all this wider spread of companies enabled us to see patterns and commonalties, gave us the confidence to generalise.

\section{The Importance of being British!}

With the benefit of hindsight being foreigners (non-Germans) was probably helpful. We wanted to do the study, we put energy into organising it, time and money into travelling into and around the former GDR, and this seemed to be recognised by the people we talked to. It heightened the complimentary interest and attention that the researcher traditionally pays to his or her subjects.

Being foreigners also liberated us from taken for granted knowledge. We could not be presumed to know, we could ask almost anything, and reward them with tales of Life in Britain! To put another slant on it, it would have been difficult for researchers who had grown up in the GDR to do what we did. They would have lacked the detachment, and might have been viewed with suspicion, and 
rightly or wrongly West German researchers might have been presumed to lack sympathy and humility. So what could be better than coming from Britain with its reputation for good natured amateurism, vagueness and under-statement. Which leads to another issue. When one masters a foreign language there is a tendency to bring to the use of this language the patterns and constructions of your mother tongue. Now there is in this sense a big difference between English and German with the emphasis on the former on controlled vagueness and non-committal generalities, and the strength of German in the sense of explicitness and specificity.

To put it another way English is a good language for the formulation of openended questions, for the coat-trailing of hints and suggestions that may evoke a response, for dangling ambiguities which the listener has to interpret and resolve - and we carried all this over into our German interviewing. To give a simple example Germans do not ask questions along the lines of: What was the GDR like?

But we did, and got answers.

Again looking back it was beneficial to have got away to a reasonably early start. Two years later, and the opportunity would have been missed. But in early 1991 it was doable. What is more at this stage memory of the communist past and of the events of the transition were vivid. We found that people seemed to want to talk about the communist past, found it almost therapeutic to do so, both in Pharma AG and in the other companies and in everyday life. Within a few months, it seemed to us, this readiness for examining the recent past was displaced by a preoccupation with the present and its abundant threats.

\section{The End of the GDR}

The story of the overthrow of the communist regime and the move to reunification does not need to be retold here, and yet we did get some new angles in conversations both with managers and more generally with ex-GDR citizens.

One point of view that was put to us was that the opposition movement attracted most support from people in their 30s and 40s. People younger than this were too brain-washed by the regime to engage in opposition; people older than this had memories of the chaos at the end of the War, die Stunde Null, and were grateful for the economic improvement since then.

This depiction of the backbone of the opposition coming from citizens in the mid part of their working lives is reinforced by another testimony, that of the orderliness and responsibleness of the opposition. The accounts made this movement sound serious and mature and well-managed in terms of personal responsibility. One interviewee actually said: 
„We drove downtown, parked in an orderly way, took part in demonstrations but were home by 10.30 to get a good night's sleep before going to work the next day."

Other testimonies suggested something of the same restraint. One of our interlocutors, for example, a university teacher working in Berlin, heard the famous announcement on East German television on the evening of Thursday 9th November 1989, but took it to mean that you could apply for a visa to visit the West in the usual way - lots of form filling, standing or queuing, delays and hassle. So he went to bed early on what turned out to be the most exciting night in the history of the GDR!

The following morning our teacher friend went to take his 9am class. All his students were there. They had spent the night carousing in West Berlin, but they came.

The immediate impact of the regime collapse/re-unification on the higher management of the VEBs is also probably not very well understood outside of Germany (perhaps not even well understood outside of the former GDR). Before we started the study we had some vague notion, if we had thought about it at all, that at least by the time of re-unification the old managers from the communist period had somehow or other been dismissed, cleared out, and magically replaced by untainted, westernized, professional managers who should stage-manage the transformation of the VEBS into the lean, mean fighting units beloved of Western business journalists. We now know this view to be quite unfounded.

What happened at Pharma is instructional here as a corrective. Throughout the period of our study Pharma was run by the same group of senior managers as had been in charge before die Wende. Sure there were one or two reallocations within the top management team, but basically it was the same team. And the Vorstand Chairman of Pharma AG was the former Generaldirektor of Pharma VEB, a much respected and charismatic figure. Indeed he was still Vorstand Chairman over a year and a half after privatisation, albeit with his power somewhat restricted by the presence on site of a representative of the new Italian owner.

Now Pharma may be an extreme case. As our study progressed, what seemed to us to be more common was that the top managers would desert their posts, or be chucked out by the workforce, at some point in 1990.

The top position would then be taken by a nominee from within the company, who had the trust of the workforce and who was pushed into the hot seat by popular acclaim. These tended to be middle managers or at least managers who were not at the very top before die Wende. Sometimes these people were known to be hostile to the regime, or had declined to join the Party (the SED) and their promotion had in consequence been held back. 
We met a number of these managers, raised by the trust of the workforce to positions of leadership. They were all impressive: sober, resolute, responsible and striving. Even VEBs that privatised at an early state by being bought by West German corporations kept, as far as we could see, most of their original East German managers: only the top one or two levels of management either ran away or were pushed out.

\section{Heroes of the Revolution}

Communist regimes in their early days like to honour 'heroes of the revolution', proletarian Stakhanovite over-achievers on the production line.

We would like to suggest that the end of communism in east Germany produced some management heroes, manfully struggling to run and rescue former VEBs in the period between re-unification and privatisation. We met a number of these acting chief executives in our research, and were much impressed by them.

First they showed initiative. None of them had prior experience of the market conditions but they were not daunted by this. They read books, went on short courses, talked to people, sometimes vicariously acquiring 'new style' management knowledge via their undergraduate sons and daughters. They were not, so to say, scared to take the car on the road before they had passed the driving test! Second, as a group they showed resolution. They did not act as caretakers, they did not simply 'mind the store' until privatisation provided new direction for the company; they comported themselves with full responsibility, as though they would be running the company for years.

This group of unsung heroes also had to do some unpopular and unpleasant things, especially dismissing significant numbers of employees. The VEBs of the former GDR were hopelessly overmanned by Western standards, for a variety of reasons we have explored elsewhere (Edwards / Lawrence 1994). As far as we can determine, apart from a few companies that went bankrupt quickly or were bought by West German companies at an early stage most of the former VEBs started slimming under their East German management well before privatisation.

This certainly applies to all the companies in our modest sample, and the scale of workforce reduction was substantial - in the $50 \%$ to $80 \%$ range.

In some instances these dismissals were quite heart-breaking. The personnel director at Pharma for example, during the communist period had set-up a manufacturing subsidiary in Siberia, an assignment lasting for months and executed in the company of a sizeable contingent of German blue-collar workers. This experience naturally brought them close together: later, before and after privatisation, this manager had to make many of these workers 
redundant. Two of the chief managers in our sample fired their wives as part of a larger slimming exercise.

Finally these managers showed in the now hackneyed phrase 'grace under pressure!' Faced with turbulent change and awesome responsibilities they struggled to master events and preserve their companies. The stresses involved took some living with.

This research exercise proved more lonely and uncertain than the commonality of research since we were foreigners in someone else's country and doing this indeed in an epoch of unprecedented system change. We have therefore been heartened to see an east German authority substantially confirming many of our own findings. Lang (1994), basing his findings on a far larger sample of managers than those interviewed in our study, like us notes inter alia that the demise of the GDR ushered in the respective rise and fall of different branches of the economy, that there was a substantial degree of continuity in company management's which was often betokened by an upward movement of respected middle managers, that managers experienced greater freedom of action and simultaneously were subjected to greater expectations and demands.

\section{The Approach to Strategy}

The Generaldirektor in the former VEB differed from his western counterpart in not having a responsibility for corporate strategy.

In a command economy, by definition, the people who run manufacturing establishments are governed by the Plan, have output-objectives presented to them, are not required to show forward-looking vision nor to fit the capabilities of the company to the needs of society in a profitable manner. Their role is more reactive, their concern is with implementation. This is not to say that their job was easy: they were constrained in ways unknown to their western counterparts, so that implementation requires much managerial skill and resourcefulness. But no strategic responsibility.

In consequence companies in the former GDR after re-unification constitute a green-field site for the study of the emergence of strategy.

At a mid-point in our study with the experience of a number of former VEBs to draw on, we looked for patterns and regularities in their post-reunification actions. In our view it is possible to discern a number of phases that the former VEBs seemed to be passing through after the watershed of die Wende, viz.

- Existential Prerequisites

- Ontological Focus

- Inner Directedness

- Outer Directedness 
- Strategy Formulation

It may be helpful to 'flesh out' our understanding of these phases a little.

\section{Existential Prerequisites}

With re-unification the former VEBs come to have an independent existence. They are no longer units on a larger system with prescribed goals. They become independent, existentially self-sufficient, have to function forthwith as ends in themselves; they have to develop intentions leading to achievements which will permit growth or at least continued existence. But in the first instance they are thwarted by the effects of currency union, the break up of COMECON, major discontinuity in the East European political system. So their first need is survival. And this may call for desperate, adaptive measures.

In the early days at Pharma, for example, a variety of employees (they had at this stage no sales reps in the Western sense) went in their own cars and on bicycles to visit East German hospitals and medical practices in the hope of protecting or re-capturing their domestic market from West German competition.

Independence nurtured by survival is the first prerequisite of strategy.

\section{Ontological Focus}

In this early stage senior managers address the question of what the organisation is, and typically put energy into changing its size, shape and boundaries.

First of all the transformed VEBs were 'unhooked' from the Kombinate with which they had been vertically integrated under communism. Where R \& D activity had been 'bulked' at Kombinat level it was now decentralised to the constituent former VEBs (or disappeared altogether). Second managers recognised that there was no longer a need to hoard labour or stockpile materials, that Autarkiestreben was no longer appropriate. So inventories were run down, sub-units such as maintenance and in-house component manufacture were hived off, cleaning and catering were outsourced, workplace-based medical clinics were externalised, while other activities of a social nature, for instance kindergartens or holiday homes, were often closed down. Third companies now had choice with regard to their product range, and began to consider what they should and should not produce.

Typically this led to a more concentrated product portfolio and the discarding of side lines.

These changes were often accompanied by a measure of decentralisation, in the formal structural sense. 
This in turn reflected the new ethos of Ende der Regression (the buck stops here), the end of the need for managers to endlessly seek confirmation of orders and authorization for their acts. So that not only did organisational shape and structure change but so did manager behaviour.

There was also typically a reallocation of manpower within the organisation. Production tended to be rationalised. It was possible to overcome the multiple inefficiencies of the GDR that had frustrated efficient manufacturing, and the size of the strictly production workforce could be reduced.

Again the purchasing function was no longer critical as it had been in the communist period. Companies could now buy raw materials and components on the outside market, from western suppliers if they chose, and often there was competition to supply them. Again the purchasing function is a candidate for slimming.

At the same time companies often had to create distribution systems, in both the institutional and logistical senses. They needed to build up sales forces and to develop a marketing capability.

So that while overall companies reduced the size of their work force there were also internal transfers reflecting the new market conditions.

What lies behind these changes is a preliminary form of strategic thinking. The competence of the company is being adapted to changed external circumstance of a dramatic kind. Yet the thinking at this stage is largely reactive. It is in the next phase that managers articulate a key question: what do we have to do to compete with West German companies?

\section{Inner-directedness}

When managers in the former GDR compared their organisations to companies in West Germany they were conscious that their own were backward, technologically primitive, and marked by low productivity. They sought to remedy this state of affairs.

First of all there was substantial investment in the company itself. Clearly there was a backlog from the past, and new computer and communications systems were introduced to provide management information and administrative support. There was also a considerable investment in training and development for managers and other workers as well as for redundant employees. But the bulk of the investment went into tangible aspects of the company's activities. New plant and equipment were acquired, the appearance of administrative buildings was upgraded, the general appearance of company sites was improved, with increasing space for employee car parks. 
This investment and particularly the costly investment in production technology had to be paid for, and this was achieved in a variety of ways. Some companies, and our Pharma AG was a case in point, were able to fund this investment out of retained earnings. Others managed to get the Treuhand to pay, arguing that technological upgrading would attract potential buyers and lead to swifter privatisation. Still other companies organised loans from banks. Another possibility was raising money by disposing of assets. It was common in the GDR for a VEB to be spread across several sites, or more properly to have a main works plus satellites. With work force shrinkage and rationalisation both of production and product range not all of these sites were needed, so that it was sometimes possible to sell or rent out real estate.

Referring to the principal thrust during the inner-directedness phase there were also substantial efforts to raise the level of production quality, for example by meeting internationally recognised GMP (good manufacturing practice) norms.

The result of this inner-directedness was, in general, an improvement in productivity and product quality. When combined with a critical evaluation of the product range indicated in the previous section the gains in efficiency were substantial (although partially subsidized by the lower, albeit rising, relative wage costs).

Two or three years after communism companies could frequently demonstrate many tangible features of the transformation they had undergone. However, companies were eventually forced to recognise that what we have labelled here as inner-directedness initiatives, however well-implemented, did not guarantee success in the market place. While investment in tangibles had, in many cases, proceeded at a rapid pace, there seemed to have been insufficient investment in intangibles such as specialist knowledge in marketing and marketing research. Some companies, after investing in new plant and modernising the product range, sat back and waited for orders to come in! In short these innerdirectedness measures may well have been a necessary condition of eventual success, but these were not sufficient in themselves to guarantee it.

We have given some emphasis to this inner-directedness phase for three reasons:

- All the companies of which we had knowledge engaged in these innerdirected initiatives

- With its core Technik emphasis this phase is characteristically German (rather than ex-communist)

- some of the companies seemed not to progress beyond this phase, at least not by 1994 and prior to privatisation. 


\section{Outer-directedness}

This phase is marked by a growing awareness of external considerations, and the adoption of measures to deal with them. A key consideration is the understanding by managers of the degree of acceptance likely to be enjoyed by the company in the outside (western) world, where rightly or wrongly former GDR companies will be regarded with some caution.

This stage is marked in particular by

- an assessment of markets

- an assessment of the competition

- the ability to distinguish between the company's products and those of rivals and to identify any competitive advantage enjoyed by the former

A key feature in this stage is the building up of a salesforce, and real efforts to develop marketing competence. In our experience there was a tendency for companies to talk about sales and marketing at a early stage, but without following through on it. When it actually happens, the outer-directedness phase has been reached.

\section{Explicit Formulation of Strategy}

It should be said straight away that nobody 'rings a bell' when a company reaches this stage; it is processual rather than a point in time.

Nonetheless there is a real distinction between this phase and the one that precedes it. The evaluation of alternative products and markets becomes more systematic. There is a move to proactivity. That is to say there is a recognition that some options can be generated, can be engineered by the actions of the company, and that beneficial options should be exploited. What is more at this stage the deliberations of management are underpinned by an understanding of the strengths and weaknesses of the company. Again this stage is marked by managers' ability to perceive linkages between strategy and operations.

At the end of the day strategy has to be:

- conscious

- intentional

- it must relate the organisation to its environment

- it should give meaning to a range of operational activities, and co-ordinate initiatives.

This, of course, is asking a good deal of management, and it is not suggested that the managers of every company in the west would meet these criteria. Our former GDR sample is not a large one, but with this qualification we would have to say that some of the companies we visited did not get to this stage, at least not before privatisation. 


\section{Entrepreneurs}

So far the discussion has centred on the development of former VEBs awaiting privatisation, and this is intentional. We would, however, also like to note the presence of an entrepreneurial spirit in the former GDR. Our research covered a reasonably detailed study of one business start-up and our sample included some management buyouts (MBOs). What is more the numbers of MBOs might well have been higher if:

- former GDR citizens had not been handicapped in attempts to raise finance

- the Treuhand had taken a more sympathetic view of MBOs.

These entrepreneurs impressed us in several ways. First they did satisfy the classical criterion of taking risk, and did so emerging from a (communist) environment marked by the absence of risk-taking, marked indeed by a high level of basic security. But more important than this they demonstrated initiative and resourcefulness. They showed initiative in the early moves to found or take over a business. They were proactive in trying to remedy their own deficiencies in regard to western business practice. They were resourceful in finding partners, raising finance, finding people to help them.

They were also quite good at thinking through what it was they had to offer, how their product or service might be depicted as different or superior. Similarly they showed enterprise in developing and securing sales leads, in organising market entry.

Another feature that they had in common is that they showed themselves to be 'good Germans' in the sense of the inner-directedness phase described in the previous section. That is to say they attached importance to work force training and were ready to spend on it. But above all they went for better/newer equipment and for improved production technology.

At times on our contact with these entrepreneurs, we were reminded of our earlier experiences in West Germany, where the 1950s were a blaze of entrepreneurial drive and money making.

\section{Ossis and Wessis}

Our study naturally gave us some exposure to the tensions existing between East and West Germans.

Regarding the role of the Treuhand it seems to us that there was a structural tension in the sense that the two sides had different priorities. The first priority for the Treuhand was to achieve the privatisation of the former VEBs and to get the best price possible. But the first priority for the managers in the companies was with likely consequences of privatisation for the workforce and for the operations of the company. For the Treuhand any buyer and a good buyer; for the former VEBs most buyers are threatening. 
Against the background of these unescapable tensions some criticisms of the Treuhand's role were made to us. The first is that the Treuhand, as noted earlier, seemed ill-disposed to management buyouts. This was interpreted as a negative judgement of the executive capabilities of former GDR managers, and was resented as such. The second criticism is that the Treuhand did not appear to pursue any industrial policy as for example had been the case in post-war France under the Fourth Republic (MacArthur / Scott 1969). That is to say they could see no moves on the part of the Treuhand to preserve some sectors or give priority to some industries, to attempt some post unification competitive strength for the New Federal States.

At a more personal level managers in the companies we visited and contacts in the former GDR generally did express a view of the West Germans they had come to know as colleagues in the work place. This view was not overwhelmingly critical, though it included a critical element. In short the conviction was that the West Germans were respected for their energy, competence, and achievement. At the same time they seemed to the East Germans, newly liberated from communism, to be too openly ambitious, too obviously committed to an individualistic ethic of self-advancement.

This, however, is not the whole story. We also had a variety of positive testimonies regarding particular instances. The Betriebsrat at Pharma AG, for instance, spoke warmly of the West German trade union, of the training and support they had received from it. The entrepreneur who set up his own business after re-unification used the Yellow Pages to find a possible business partner in the West. He succeeded, and the partner offered capital, equipment, and business know-how. Then when the enterprise succeeded this West German partner agreed to be bought out making our entrepreneur the sole owner.

Or again the chief executive of one of the MBO companies again used the Yellow Pages to try to find assistance from a practitioner in the same industry in the 'West German' town close to the old BRD-DDR border. He has succeeded, and enjoyed help with putting business systems into place and introductions to suppliers. The West German also offered training/experience to the MBO company's employees by deploying them on work sites in the West.

The chief executive of the MBO company was touched by all this, and offered his West German benefactor a partnership. The response from the West was: Your offer honours me, but I do not seek gain.

We would like to suggest that the stereotypes of the last few years do not tell the whole story. 


\section{References}

Edwards, V. (1979): The Organisation of Management Education in East Germany. Journal of European Industrial Training. 3.1. pp 29-32.

Edwards, V. / Lawrence, P. (1994): Management Change in East Germany. Routledge / London.

Lang, R. (1994): Führungskräfte in Ostdeutschland. Arbeitspapier 03. Lehrstuhl für Organisation und Arbeitswissenschaft. Technische Universität Chemnitz-Zwickau.

Lawrence, P. (1980): Managers \& Management in West Germany. Croom Helm. London.

MacArthur, J. J. / Scott, B. (1969): Industrial Planning in France. Harvard Business School. Boston. 